\title{
RANCANG BANGUN APLIKASI PERPUSTAKAAN DI SMP NEGERI 176 JAKARTA
}

\author{
Rahmi Nilam Aceh ${ }^{1}$, Dwi Yulistyanti ${ }^{2}$, Tria Hadi Kusmanto ${ }^{3}$ \\ Program Studi Teknik Informatika, Fakultas Teknik dan Ilmu Komputer, \\ Universitas Indraprasta PGRI \\ Jalan Raya Tengah No 80, Kelurahan Gedong, Pasar Rebo, Jakarta Timur \\ Rahmiaceh98@gmail.com ${ }^{1}$, unindra.dwiyulist@gmail.com², triahadiunindra@yahoo.co.id ${ }^{3}$
}

\begin{abstract}
Abstrak
Merancang Aplikasi Perpustakaan Berbasis Android yang merupakan pengembangan dalam hal pelayanan pada perpustakaan SMP Negeri 176 Jakarta. Perpustakaan SMP Negeri 176 Jakarta memiliki koleksi buku yang cukup menambah wawasan para siswa dalam mencari ilmu namun para siswa cenderung malas untuk mencari buku di perpustakaan. Permasalahan dibuatnya aplikasi perpustakaan ini adalah dikarenakan masih ditemukan beberapa petugas yang cenderung kuranf peduli terhadap kebutuhan pengunjung, hal ini dapat mempengaruhi kepuasan pengguna terhadap pelayanan yang ada pada bagian pelayanan perpustakaan di SMP Negeri 176 Jakarta. Daftar buku masih dituliskan dikertas sehingga susah untuk mensortir, mencari dan mengelola koleksi buku tersebut. Kurang efisien dan akurat sehingga membuat proses operasional tersebut menjadi lambat. Pengecekan ketersediaan buku secara digital tidak bisa dilakukan. Data mudah hilang dan mengharuskan mendata ulang. Masih terjadi kesulitan dalam penyimpanan data buku karena tidak adanya database yang teraplikasi. Dengan dibuatnya aplikasi perpustakaan berbasis android ini siswa dapat mengetahui informasi ketersediaan buku serta dapat meminjam jauh hari melalui smartphone kapan dan dimana saja. Sehingga tidak memakan waktu yang cukup lama dalam mencari buku yang dibutuhkan di perpustakaan
\end{abstract}

Kata Kunci: Rancang Bangun, Perpustakaan, Android

\begin{abstract}
Designing Android-Based Library Application which is a development in terms of service at SMP Negeri 176 Jakarta library. SMP Negeri 176 Jakarta Library has a collection of books that add enough insight to the students in finding knowledge but the students tend to be lazy to look for books in the library. The problem with the making of this library application is because there are still some officers who tend to be less concerned with the needs of visitors, this can affect user satisfaction with the existing services in the library services section at SMP Negeri 176 Jakarta. The list of books is still written on paper so it is difficult to sort, find and manage the collection of books. Less efficient and accurate, making the operational process slow. Digital book availability checks cannot be performed. Data is easily lost and requires relogging. There are still difficulties in storing book data due to the absence of an application database. With the making of this android-based library application, students can find out information on the availability of books and can borrow long days through smartphones anytime and anywhere. So, it does not take long enough in finding the necessary books in the library.
\end{abstract}

Keywords: Design, Library, Android.

\section{PENDAHULUAN}

Perkembangan ilmu dan teknologi mendorong perkembangan sistem administrasi berbasis teknologi. Hal tersebut juga merambah kepada manajemen perpustakaan SMP Negeri 176 Jakarta, termasuk salah satunya dalam pengolahan sistem perpustakaan. Menurut (Christianti J.\&Pasha, 2012) sistem adalah kumpulan unsue-unsur yang bergabung menjadi satu kesatuan dan mempunyai tujuan yang sama. Peningkatan profesionalisme dan kualitas pendidikan serta pelayanan yang ditawarkan suatu lembaga pendidikan merupakan salah satu daya tarik yang menjadi perhatian masyarakat sebagai salah satu kriteria dalam suatu lembaga pendidikan. 
Mengelola suatu perpustakaan membutuhkan suatu sistem yang terancang dengan baik. Perpustakaan bertujuan sebagai sarana dalam menyediakan buku-buku untuk siswa yang ingin membaca dan mencari informasi buku yang mereka perlukan (Sari \& Setyadi, 2017). Adapun pengertian perpustakaan sekolah menurut (Santi, 2014) perpustakaan sekolah adalah perpustakaan yang berada pada satuan pendidikan formal di lingkungan pendidikan dasar dan menengah yang merupakan bagian integral dari kegiatan sekolah yang bersangkutan, dan merupakan pusat sumber belajar untuk mendukung tercapainya tujuan pendidikan sekolah yang bersangkutan. Ratusan jumlah buku dan anggota yang terdaftar di perpustakaan harus didata dengan tepat dan efisien. Cara manual dengan pencatatan dikertas dalam mengelolanya dirasakan tidak optimal. Misalnya pada perpustakaan SMP Negeri 176 Jakarta. Berbagai informasi data buku perpustakaan harus dicari satu persatu tanpa mengetahui ketersediaan buku yang dicari ada atau tidak.

Dengan latar belakang tersebut, peneliti mengambil penelitian untuk bahan skripsi atau tugas akhir ini dengan judul "Rancang Bangun Aplikasi Perpustakaan di SMP Negeri 176 Jakarta Berbasis Android" dengan harapan siswa dapat mencari buku yang diinginkan melalui aplikasi, sehingga memudahkan pencarian buku tanpa harus mendatangi tempat perpustakaannya. Dengan demikian dapat menghemat waktu dan sangat membantu siswa yang sibuk untuk mendapatkan buku yang diperlukan.

\section{PENELITIAN RELEVAN}

Pada awal penelitian, peneliti telah melakukan beberapa pengamatan mengenai sistem di SMP Negeri 176 Jakarta terutama dalam sistem Perpustakaan, dimana saat proses pencatatan dan peminjaman buku berlangsung masih dilakukan secara manual sehingga dapat menyebabkan hilangnya berkas dan proses pencarian data yang lambat. Dengan demikian ada beberapa penelitian yang menjadi acuan peneliti untuk membuat sistem informasi tersebut antara lain.

Penelitian pertama diambil dari jurnal dengan judul (Parmawati \& Sukayana, 2016)Aplikasi Online Public Access Cataloque (Opac) Berbasis Android Sebagai Sarana Temu Kembali Informasi di Perpustakaan Universitas Pendidikan Ganesha dengan hasil penelitian Aplikasi OPAC berbasis android ini cukup layak untuk digunakan sebagai alternatif pelengkap pemberian layanan penelusuran informasi koleksi buku teks umum di Perpustakaan Undiksha.

Penelitian yang kedua diambil dari jurnal dengan judul (Wijaya \& Sari, 2015)Rancang Bangun Mobile Commerce Berbasis Android Pada Toko Duta Buku Semarang dengan hasil penelitian Aplikasi mobile commerce penjualan buku online dapat mempermudah pelanggan dalam mencari informasi buku dan melakukan transaksi pembelian serta dapat memperkenalkan toko Duta Buku sehingga dapat meningkatkan jumlah penjualan.

\section{METODE PENELITIAN}

Metode pengembangan sistem yang digunakan adalah metode R\&D (Research and Development. Dalam penelitian ini menggunakan metode penelitian dan pengembangan atau lebih dikenal dengan Research and Development. Metode penelitian dan pengembangan adalah metode penelitian yang digunakan untuk menghasilkan produk tertentu, dan menguji keefektifan produk tersebut (Joyo Sampurno et al., 2015).

\section{Metode Pengumpulan Data}

Dalam mengumpulkan data, keterangan dan rancangan program yang dibutuhkan untuk Rancang Bangun Aplikasi Perpustakaan SMP Negeri 176 Jakarta Berbasis Android, peneliti menggunakan 2 (dua) metode yaitu:

\section{Metode Observasi}

Observasi merupakan pengamatan langsung terhadap suatu objek yang ada di lingkungan yang sedang berlangsung meliputi berbagai aktivitas perhatian terhadap kajian objek dengan menggunakan pengindraan (Lukmantoro Taufik, Kurniasari, Triliana, 2013). Dalam hal ini, observasi dilakukan selama bulan Maret 2018 di Perpustakaan SMP Negeri 176 Jakarta. Dengan mengamati dan melihat bagaimana proses peminjaman buku, pencarian buku, dan pengembalian buku yang dilakukan oleh siswa dan petugas perpustakaan.

\section{Studi Kepustakaan}


Studi Kepustakaan merupakan pendukung penelitian yang berasal dari pandangan-pandangan ahli dalam bentuk yang tertulis berupa referensi buku, jurnal, laporan penelitian atau karya ilmiah lainnya (Handayani, 2016)

\section{HASIL DAN PEMBAHASAN}

Dengan melihat masalah yang ada, telihat bahwa seringkali petugas perpustakaan dan juga siswa kesulitan siswa dalam mengelola mensortit dan mencari koleksi buku yang ada, sehingga informasi buku sangat minim. Penerapan aplikasi perpustakaan di SMP Negeri 176 Jakarta berbasis android mampu memberikan kemudahan bagi para siswa khususnya untuk siswa-siswi SMP Negeri 176 Jakarta untuk mengetahui ketersediaan buku yang dicari, dan juga untuk memudahkan petugas perpustakaan untuk menginput data buku. Berikut ini merupakan penggambaran tentang metode yang digunakan pada rancang bangun aplikasi perpustakaan SMP Negeri 176 Jakarta Berbasis Android dengan UML. Menurut (Munawar, 2018) UML (Unified Modelling Language) adalah salah satu alat bantu yang sangat handal di dunia pengembangan sistem berorientasi obyek.

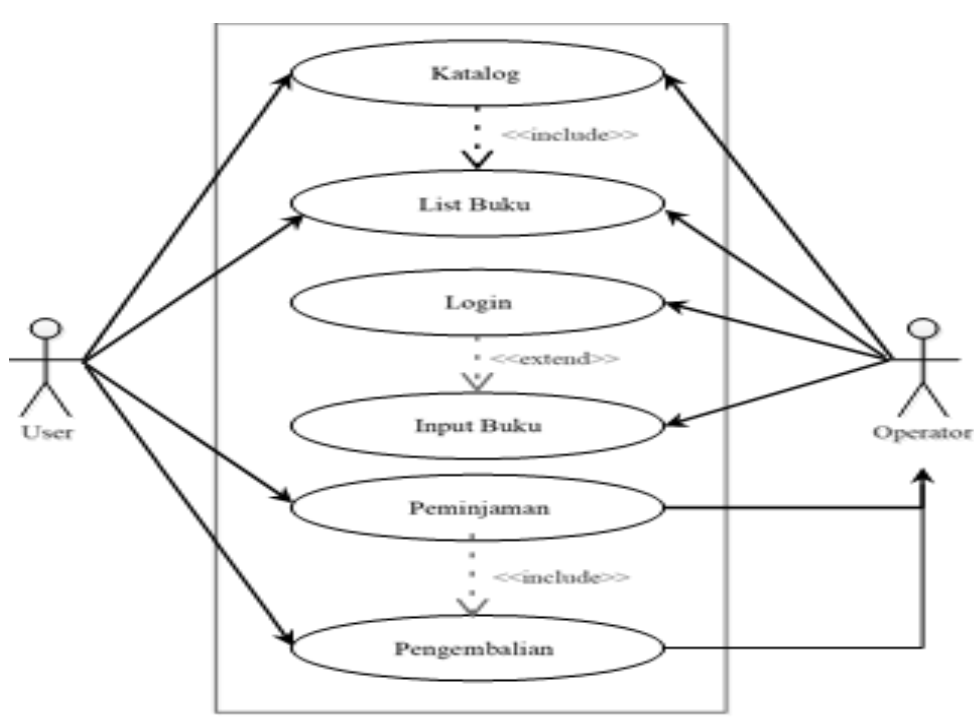

Gambar 1. Use Case Diagram

Gambar diatas merupakan Use Case Diagram yang menampilkan alur pemakaian aplikasi. Katalog menampilkan daftar buku berdasarkan kategori mata pelajaran, list buku menampilkan isi buku dari kategori yang sebelumnya dipilih, login mendeskripsikan tampilan halaman login untuk user dan operator, input buku menampilkan proses menambahkan dan mengubah buku saat ini untuk seterusnya akan dilihat oleh siswa, peminjaman menampilkan proses meminjam buku dengan mengisi nama dan tanggal peminjaman, dan pengembalian menampilkan proses pengembalian buku yang telah dipinjam. 


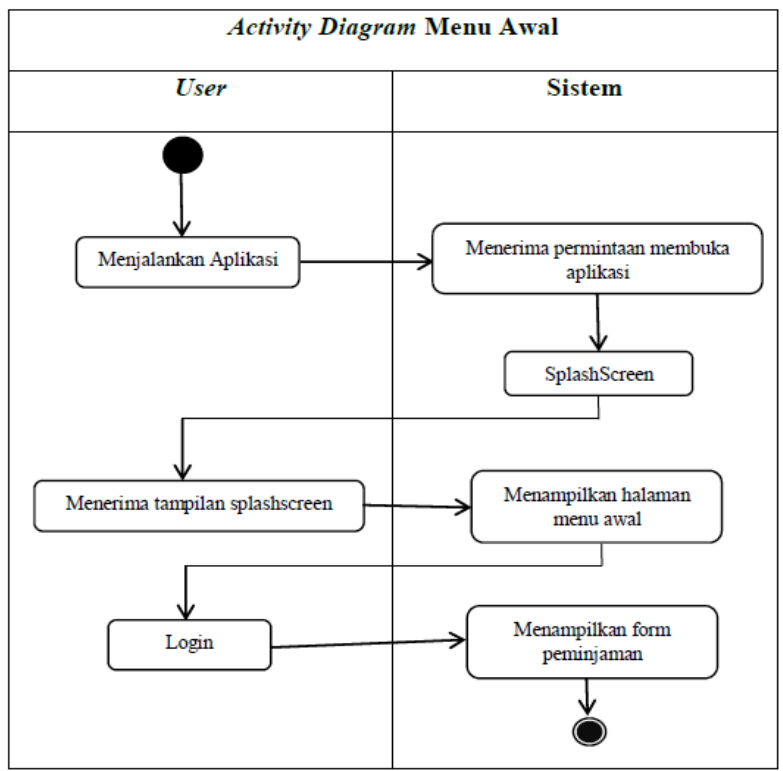

Gambar 2. Activity Diagram

Gambar diatas adalah activity diagram yang lebih menggambarkan tahapan proses dan jalur aktivitas pada sistem yang akan berjalan didalam sebuah aplikasi. Pada bagian pertama saat membuka aplikasi, user akan melihat tampilan splash screen selama beberapa detik, kemudian menampilkan menu awal aplikasi yang terdiri dari 4 menu antara lain (Ilmu Pengetahuan Alam, Matematika, Bahasa dan Ilmu Pengetahuan Sosial) serta dilengkapi dengan tombol Login yang berfungsi untuk membawa user yang diizinkan untuk melihat Form Peminjaman.

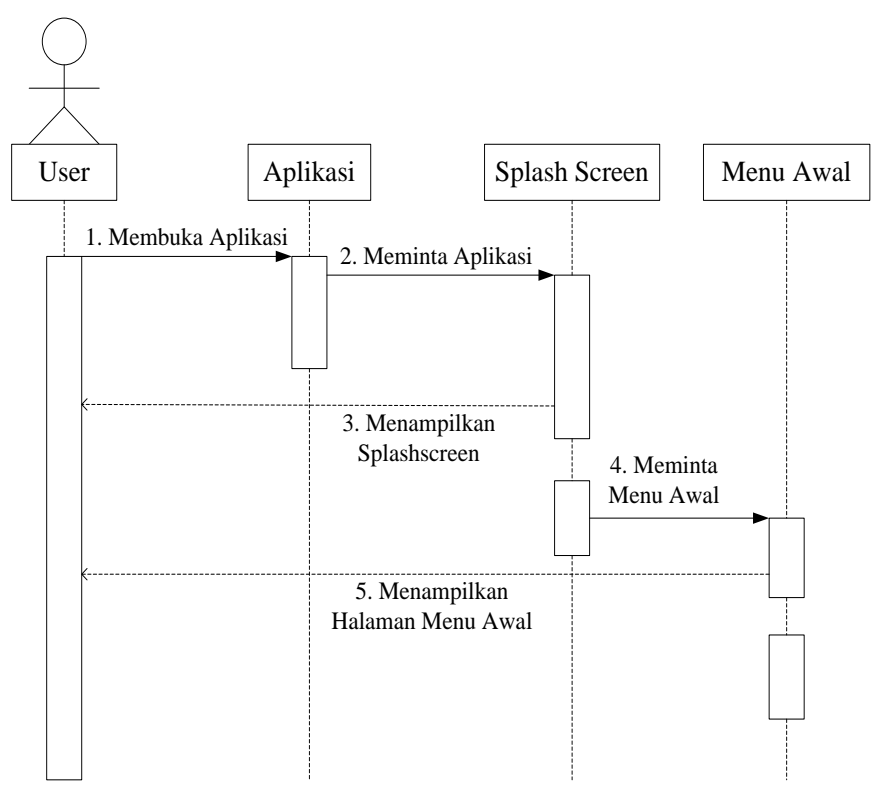

Gambar 3. Sequence Diagram

Gambar diatas adalah Sequence Diagram yang merepresentasi dari interaksi-interaksi objek yang berjalan pada sistem. Dari gambar diatas terlihat user membuka aplikasi, kemudian tampil splash screen, sistem meminta menu awal yang kemudian halaman menu awal ditampilkan kepada user. 


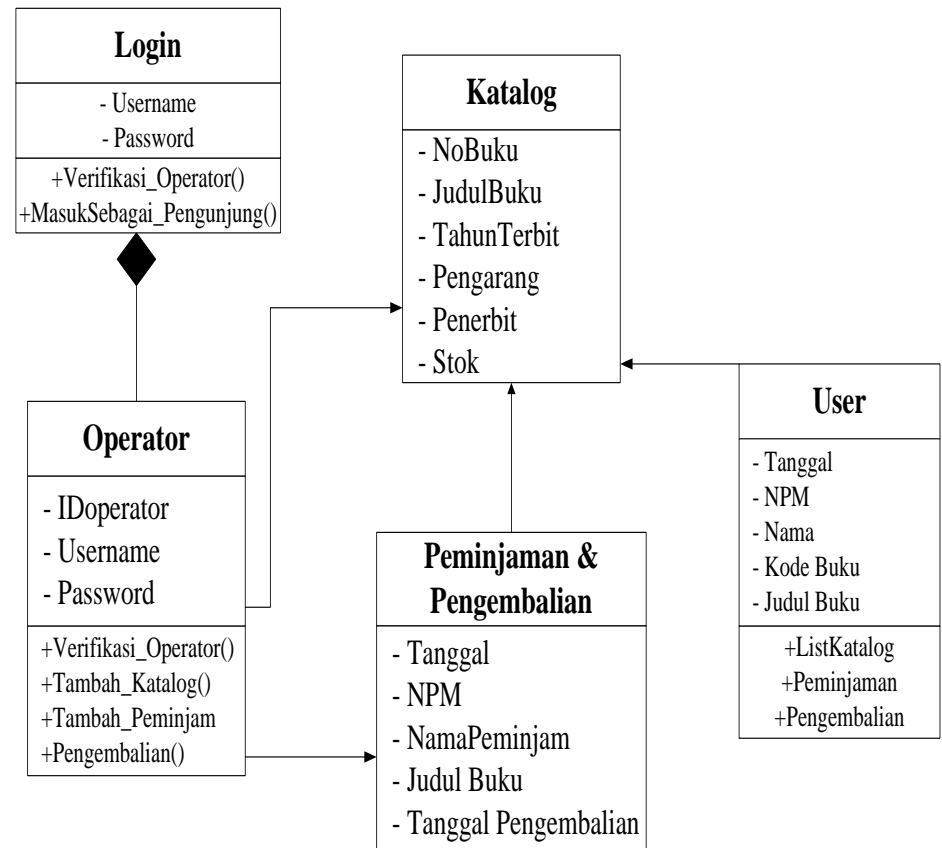

Gambar 4. Class Diagram

Selanjutnya peneliti membuat aplikasi menggunakan Android Studio dan database mysql. Berikut ini adalah tampilan dari Aplikasi Perpustakaan SMP Negeri 176 Jakarta.

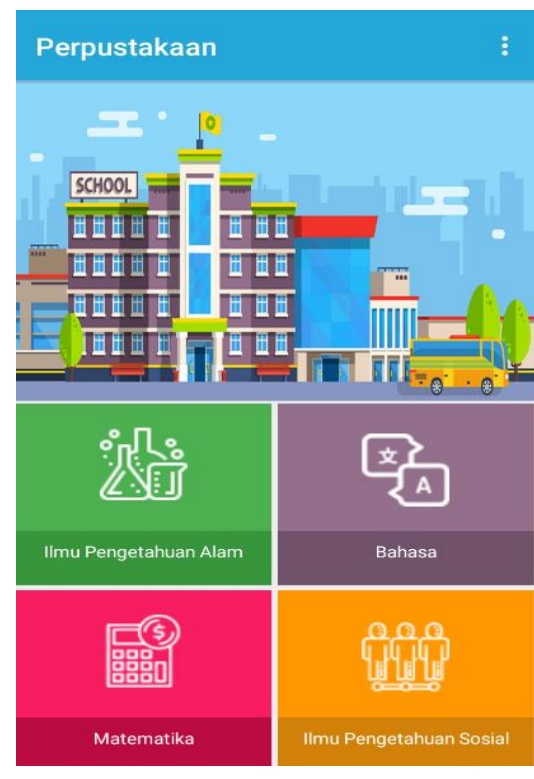

Gambar 5. Tampilan Menu Awal

Pada gambar diatas menampilkan menu utama saat membuka aplikasi, berisikan katalog buku dan tombol login untuk masuk sebagai petugas perpustakaan 


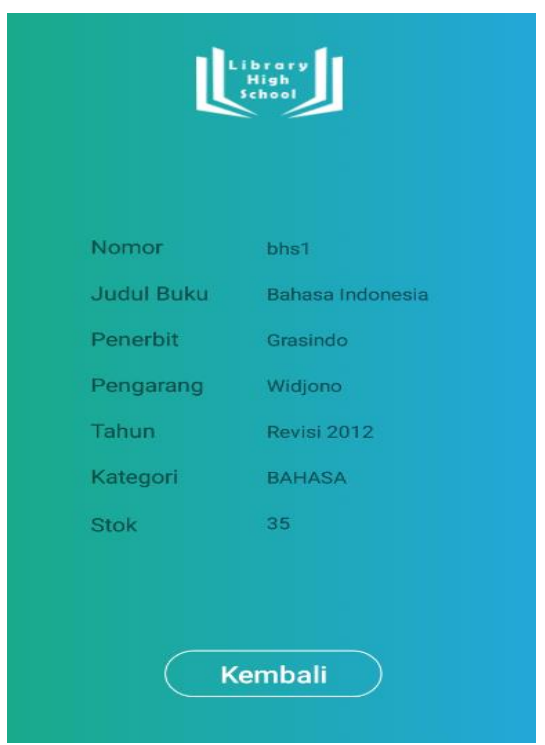

Gambar 6. Tampilan Menu Detail Buku

Gambar diatas menunjukan deskripsi buku yang ingin dipinjam, terdiri dari nomor, judul buku, penerbit, pengarang, tahun, kategori dan stok.

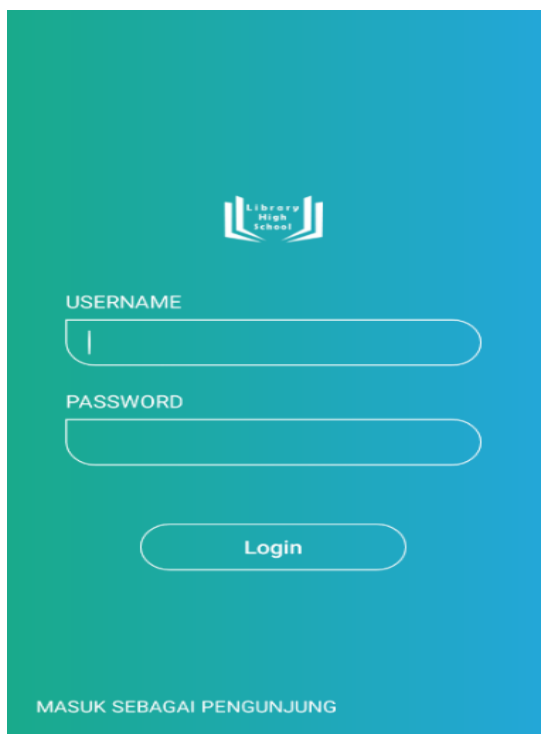

Gambar 7. Tampilan Menu Login Operator

Pada gambar diatas, pengguna akan diarahkan untuk memasukkan data autentikasi untuk masuk sebagai petugas perpustakaan atau sebagai pengunjung 


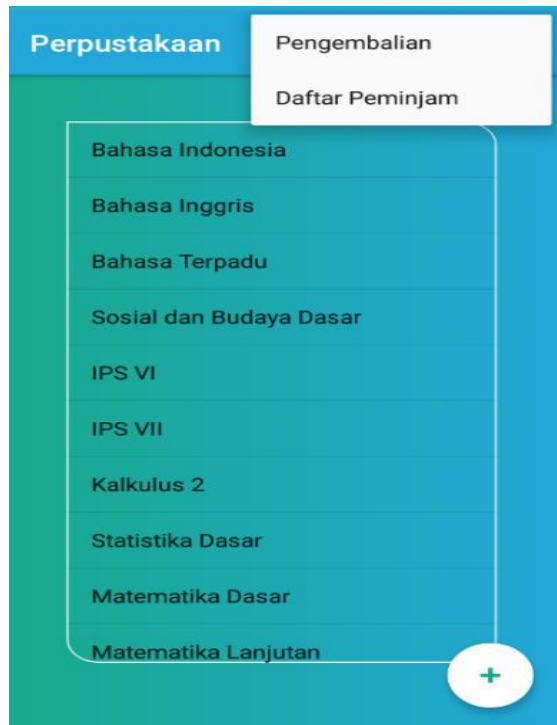

Gambar 8. Tampilan Menu Utama Operator

Tampilan Menu Utama Operator menampilkan daftar buku yang tersedia setelah petugas perpustakaan melakukan login.
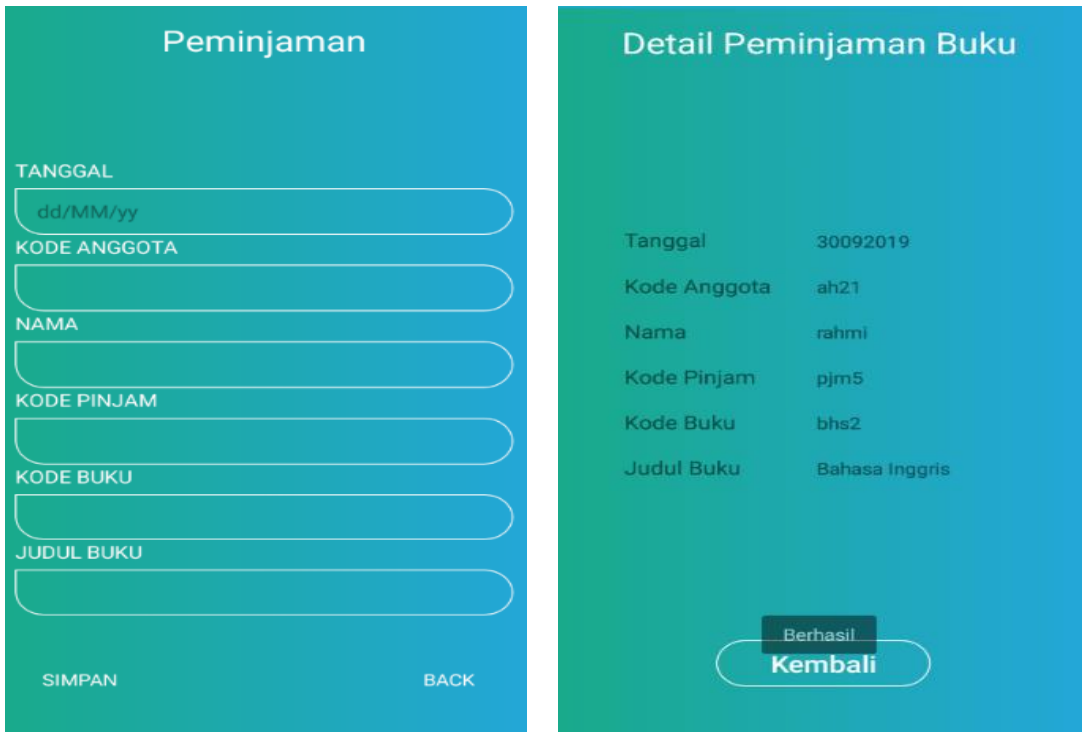

Gambar 9. Tampilan Menu Peminjaman

Tampilan Menu peminjaman berguna untuk membantu pengunjung untuk melakukan peminjaman atau booking buku terlebih dahulu sebelum mendatangi perpustakaan, sehingga memudahkan pengunjung dan tidak berfokus pada pencarian buku pada rak. 

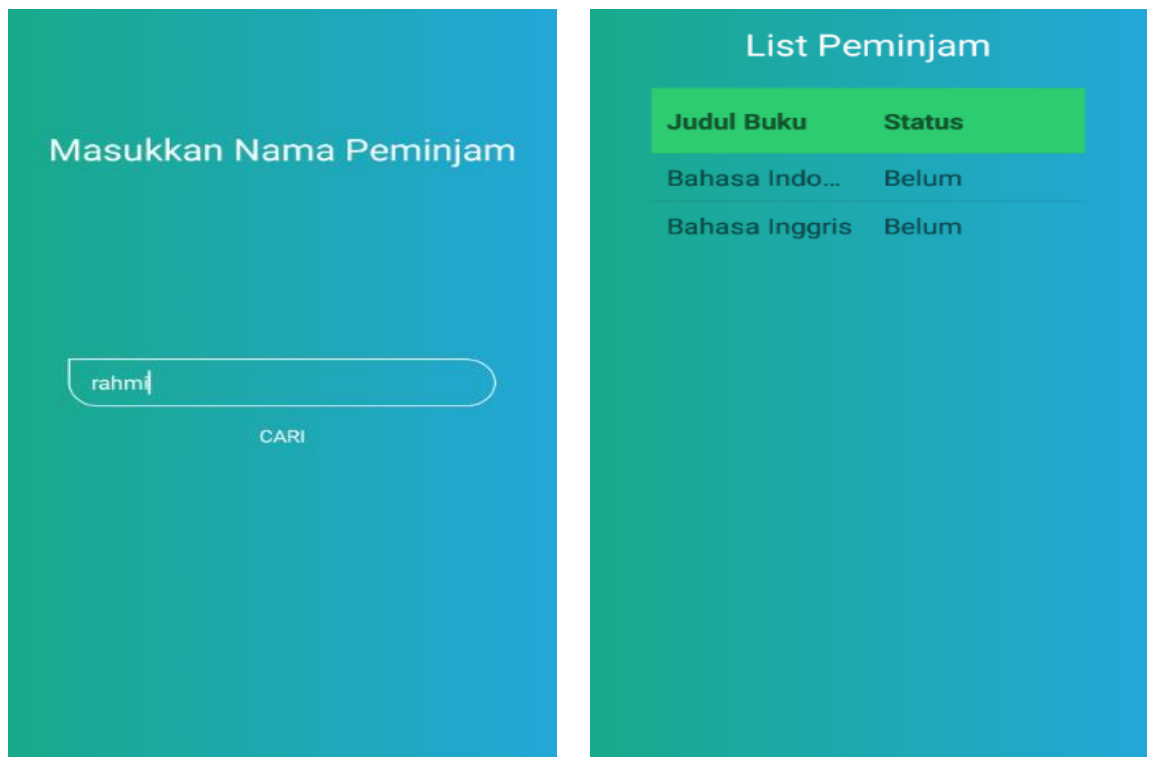

Gambar 10. Tampilan Menu Pengembalian Buku

\section{SIMPULAN}

Dengan dibuatnya Aplikasi Perpustakaan SMPN 176 Jakarta, semua kegiatan yang berhubungan dengan perpustakaan dapat berjalan dengan baik dan lancar. Pada aplikasi ini, operator dapat menangani pekerjaan penginputan data buku dengan cepat dan akurat serta dapat ter-update dengan mudah. Dengan adanya aplikasi ini diharapkan akan mempermudah kegiatan atau aktivasi pekerjaan yang memerlukan kecepatan dan ketepatan informasi.

Kecepatan dan ketepatan informasi ini juga membutuhkan partisipasi aktif dari operator dan menginput data buku. Dengan adanya Aplikasi perpustakaan ini sebagai alat bantu, peneliti mempunyai simpulan sebagai berikut :

1. Aplikasi Perpustakaan SMPN 176 Jakarta Berbasis Android ini menyediakan akses informasi ketersediaan buku kepada pengguna atau siswa SMPN 176 Jakarta sehingga mudah digunakan dimana saja.

2. Aplikasi Perpustakaan SMPN 176 Jakarta ini mampu menangani proses penginputan data buku secara online yang melibatkan operator dan pencarian buku yang melibatkan siswa.

\section{DAFTAR PUSTAKA}

Christianti J., M., \& Pasha, A. A. (2012). Aplikasi Circulation Information System ( CIS ) dengan Studi Kasus. Journal of Information Systems Volume 7 No 1.

Handayati, R. (2016). Analisis Faktor-Faktor Yang Mempengaruhi Tingkat Kepuasan Konsumen Di Pong-Pong Cafe Lamongan. Jurnal Penelitian Ekonomi Dan Akuntasi.

Joyo Sampurno, P., Maulidiyah, R., \& Zuliana Puspitaningrum, H. (2015). Implementasi Kurikulum 2013: MOODLE (Modular Object Oriented Dynamic Learning Environment) dalam Pembelajaran Fisika melalui Lembar Kerja Siswa pada Materi Optik di SMA (Halaman 54 s.d. 58). Jurnal Fisika Indonesia. https://doi.org/10.22146/jfi.24361

Lukmantoro Taufik; Kurniasari, Triliana, T. S. (2013). Eksistensi Graffiti sebagai Media Ekspresi Subkultur Anak Muda. Interaksi Online.

Munawar. (2018). Analisis Perancangan Sistem Berorientasi Objek dengan UML. Informatika Ban.

Parmawati, P. T., \& Sukayana, P. (2016). APLIKASI ONLINE PUBLIC ACCESS CATALOQUE (OPAC) BERBASIS ANDROID SEBAGAI SARANA TEMU KEMBALI INFORMASI DI PERPUSTAKAAN UNIVERSITAS PENDIDIKAN GANESHA. JST (Jurnal Sains Dan Teknologi). https://doi.org/10.23887/jst-undiksha.v5i1.8279

Santi, T. (2014). Membangun Citra Pustakawan Iain-Su Medan. Jurnal Iqra.

Sari, N. M., \& Setyadi, A. (2017). PEMANFAATAN PERPUSTAKAAN OLEH GURU IPS DALAM MENUNJANG KEGIATAN BELAJAR-MENGAJAR DI SMA NEGERI 2 PURBALINGGA. Jurnal Ilmu Perpustakaan.

Widodo, W. (2016). EVALUASI PROSES PENGEMBANGAN PERANGKAT LUNAK PADA VIRTUAL TEAM $\begin{array}{llllll}\text { DEVELOPMENT MENGGUNAKAN CMMI Versi } & \text { 1.3. Jurnal Informatika. }\end{array}$ https://doi.org/10.26555/jifo.v10i1.a3345

Wijaya, H., \& Sari, W. S. (2015). Rancang Bangun Mobile Commerce Berbasis Android Pada Toko Duta Buku Semarang. Techno.Com. 